Indonesian Journal of EFL and Linguistics

Vol. 6 No. 1, 2021

eISSN: 2503-4197, pISSN: 2527-5070

www. indonesian-efl-journal.org

doi: http://dx.doi.org/10.21462/ijefl.v6i1.337

\title{
From Clause to Function: Texts Analysis Using Systemic Functional Linguistics Theory and Its Pedagogical Implication in Language Teaching
}

\author{
Hieronimus Canggung Darong \\ Universitas Katolik Indonesia Santu Paulus \\ e-mail: ronybarera@yahoo.co.id
}

\begin{abstract}
:
Using Systemic Functional Linguistics (SFL) theory, this study was an attempt to investigate the metafunctions of language which are realized by register category of field, tenor, and mode existing simultaneously in texts. Employing qualitative approach with the use of discourse semantics analysis, two different selected newspaper texts were purposefully chosen as the source of data. Following the orientation of SFL, the writer modified the texts into some sentences and clauses which were subsequently analysed and compared regarding the objectives in question. The result of analysis shows that the field of texts was mostly concerned with physical actions and events employing both direct and indirect speech for the sake of information. Meanwhile, in terms of mode, Text I was more rhetoric and more detail in describing the event than text II. Yet, the level of modality in both texts was low and low in which there were not many actions of getting other people to do things. Aside from those two, this analysis revealed that the mode of both texts mostly used anaphoric types of referential cohesion indicating written mode. In the meantime, Text I had more number of conjunctions implying more explanative in giving information and cause and effect relation of the information. Of greater importance of this finding was that a paradigmatic description of context implying a meaning, system, and metafunctions of language and its pedagogical implication in language teaching.
\end{abstract}

Keywords: metafunction, register, SFL, text

Indonesian Journal of EFL and Linguistics, 6(1), 2021 


\section{Hieronimus Canggung Darong}

\section{INTRODUCTION}

Numerous research studies have been carried out regarding the analysis of the texts. For example, using factor analysis, Bartholomé, Lecheler, and Vreese (2018) examined the occurrence of the conflict news typology the role of contextual factors. Meanwhile, others focused on the relationship between image inclusion and the news theme and ideology, (Potter, 2016; Works \& Wong, 2019), the role of ordinary citizens in public discourse (Peter \& Zerback, 2020); the concern of market and culture logic, capacity and trust, and perception (Mishra, 2020; Naab, Heinbach, \& Ziegele, 2020; Rice \& Taylor, 2020; Wenzel, Ford, \& Nechushtai, 2019). Regarding the mode, some studies revealed that online news is preferably used, though more challenging for its future image and values than the printed ones (Franklin, 2014; Harcup \& Neill, 2017). Unlikely, some people still deal with print newspapers with a reason for dynamics that tie together news content with their daily lives such as materiality, routinization, (Boczkowski, Mitchelstein, \& Suenzo, 2020).

Besides, other research studies focused on rhetoric language and linguistic complexity. For example, the implications of the use of metaphors as a rhetoric dimension to employ the issues of the text (Kelly, 2020; Lule, 2007; Moragasfernández, Calvo, \& Capdevila, 2018; Nartey, 2018). Moving ahead, there was a claim that the patterns of presenting information across various media are different resulting from various linguistic resources used. As such, complexity tends to employ a different interpretation from the reader (Bartely, 2018; Tolochko \& Boomgaarden, 2017).

Highlighting the approach used, some studies mentioned employed different approaches such as modelling approach, structural approach, genre-based approach producing journalistic news Satire, Markov chain approach to discover meaningful patterns news use patterns, dichotomous framework, and socio-pragmatic methodology. Such approaches are beneficial to reveal thematic information within the text (Boch, 2020; Brookes \& Mcenery, 2019; Fetzer \& Bull, 2012; Koivukoski \& Ödmark, 2020; Schumacher, Hansen, Velden, \& Kunst, 2019; Vermeer \& Trilling, 2020).

Overall, previous studies dealt with the macro aspect of the news texts. Despite the fruitful findings of previous research studies along with the approaches used, there is a need to reveal the system of lexico-grammar within the news text. In this respect, another theory can be used in analyzing a text namely systemic functional grammar, which is popularly known as Systemic Functional Linguistics (SFL). This theory is mostly discussed nowadays in terms of discourse analysis, spoken or written discourse.

Regarding the SFL, there has been a great number of research studies in the field. For example in analyzing paralanguage referring to semiosis dependent on language and realized through both sound quality and body language (Martin \& Zappavigna, 
2019), the realization and choice of cause-effect relations in English in terms encoding logico-semantic meaning (Othman, 2020). Highlighting the comparison between SFL and Cardiff Grammar's treatment of clause combining, there was a contra found in terms of a subordinate clause upholding functional meanings (Andersen, Emilie, \& Holsting, 2018). Meanwhile, emphasizing the function of language which is realized by register category of mode, other studies were concerned with a visual tool for generating thematic expression of the text (Leong, 2019), field of the text through transitivity analysis (Guswita \& Suhardi, 2020, Montes, Barboza, \& Olascoaga, 2014)), and text type utilizing perfect construction which differs, in terms of speeds, functions, and parole such as in spoken and written English (Bao, Zhang, Qu, \& Feng, 2018; Hasan, 2014).

Unlikely, other studies emphasized the coherence bringing to the unity of texts, (Kai, 2008; Murthy \& Kumar, 2007; Poulimenou, Stamou, Papavlasopoulos, \& Poulos, 2016). The unity of text might be of benefit as the linguistic resources used properly in context. Then, dwelling deeper into the context of the instructional approach, SFL was of benefit and was aligned to the learning by design framework widely used in multiliteracies. As such, the SFL provides scaffolds for students to reveal the meanings constructed in multimodal texts by highlighting the features and typical functions of the text (Lim, 2018).

Despite the fruitful findings of previous studies, there is a need to emphasize that SFL theory relates to the function of language. It presents a functional grammar description of the metafunctional organization of the clause which is realized by field, (experiential meaning and lexical relations), tenor (interpersonal meaning and mood pattern of grammar), and mode (language role) of the text. The previous research studies, in fact, focused only on one aspect of meaning, which to the writer, regards as a hobble analysis. In the light of the SFL theory, the three aspects of meaning mentioned above exit simultaneously in the text leading to a comprehensive and wholly understanding of the text itself (Halliday, 1985; Eggins, 1994).

Again, this backdrop, this present paper attempts to employ the Systemic Functional theory covering the three systems of meanings using news articles as the sample of analysis. By taking the same issue from two different newspaper articles, the focus was on the field tenor, and mode that subsequently compared the results. This analysis could give some insights into how to deal with other kinds of texts genre.

\section{LITERATURE REVIEW}

In general, Systemic Functional Linguistics (SFL), the 'S' for 'Systemic' refers to the systemic relations and their possibilities in a system network of relations and choices pushing from general to specific features that are paradigmatic in nature. It also means that the system of meaning that is interrelated employed within the text. Meanwhile, the ' $F$ ' for 'Functional' is concerned with the functional realizations of 


\section{Hieronimus Canggung Darong}

the system in structures. As such, the system should be constructed in such a way that it has a particular function which is realized by register categories such as field, tenor, and mode. The last is L referring to the theory of Linguistics discipline and through it, the investigation of the phenomena of language might be alternatively carried out (Halliday, 1985).

The largest analysis level in the traditional grammar is the sentence, while the functional linguistics theory is the text. Functional linguistics can work with a word extent but generally is focused in wider chunks in spoken, written and multimodal texts. In this respect, the theory in question is fascinated in how the context has impacted and is revealed in the language choices within certain genre and associated with the way of meaning construction. As such, there are three categories of the meaning of the language of text namely field (experiential meaning), tenor (interpersonal meaning), and mode (textual meaning). As such, the three kinds of meaning are the metafunction of language (Eggins, 1994).

The field deals with situational variable focusing on the activity of the speakers or writers are involved. In terms of discourse-semantic, the field links to the experiential meaning and lexical relations. While, in terms of lexico-grammar, the field has to do with transitivity pattern of grammar. As Eggins (1994) states that the field of a text is connected to the realization of experiential meanings which are realized through the transitivity pattern of grammar. Furthermore, Eggins (1994) states that performing a transitivity analysis includes determining the process type, participants, and circumstances. The functional linguistics' description of the transitivity is related to the process type specifying the action, events, or relationship between participants, and the process that may be situated circumstantially. As such, the transitivity system employs six major systems (process types); material process, mental process, verbal process, behavioural process, existential process, and relational process, and one minor system (circumstantial) (Eggins, 1994). The circumstantial usually appears in all the major process type of transitivity.

The tenor is defined as the situational variable referring to the social role relationship of the interactants. It is believed that the social role of the interactants affects them on how they use language. In terms of discourse-semantic, tenor links to a conversational structure and interpersonal meaning. While, in terms of lexicogrammar, the tenor has to do with mood pattern of grammar. In this regard the tenor of a text is connected to the realization of interpersonal meanings that are realized through the mood pattern of grammar. Mood structure is used to describe how language is used to enable the expression of interpersonal meaning (Eggins, 1994; Halliday, 1985). The system of mood is of benefit for an understanding of the interpersonal relationships between interactants. As Eggins (1994) states that as language is used in interaction, one point that will come up is the establishment of the relationships between speakers or writers who speak now and who will be next. The investigation of the mood structure is begun by looking at how clauses are 
structured in exchanging proposition or information. When the clause is utilized to exchange information, it is called a proposition. Meanwhile, as the clause is ordered to exchange goods and services, then it is called proposals.

The mode is defined as the language role in an interaction. In terms of discoursesemantic, mode relates to reference and conjunction and textual meaning and in terms of lexico-grammar, it has to do with theme pattern of grammar. As coined by Eggins, (1994) the mode of a text deals with the realization of textual meanings which are realized through the theme pattern of grammar. The analysis of mode is beneficial for judging whether the text belongs to spoken or written.

Thus, Systemic functional linguistics (SFL) has introduced a system of language structure analysis reflecting the metafunction of language. The language structure analysis is realized by register the category of field, tenor, and mode.

\section{RESEARCH METHODOLOGY}

This study belongs to qualitative approach employing discourse semantics analysis method. To highlight the sentences and clauses from which the functions were revealed, the writer took two different texts as the source of data. As such, the texts were chosen solely to have a description of the metafunction of language which are realized by register category of field, tenor, and mode. In this regard, the researcher, as the main instrument, analyzed the texts to see the intended meaning utilizing systemic functional Linguistics theory.

The procedure of analyzing the texts was carried out through some ways. First, the researcher modified the texts into sentences and clauses. The modification would be of benefit for the researcher to easily analyze the texts. Second, the sentences and clauses, from which the texts were built, were analyzed under the goal of analysis that is the field, tenor, and mode of the text. Third, for the sake of field, the researcher analyzed the transitivity pattern (process types) and circumstance analysis. Meanwhile, modality and the adjunct were deeply examined in the mood structure analysis. As such, the analysis was carried in such a way that those two might reveal the tenor of the texts. The mode was examined through the lexicogrammar analysis of conjunction and reference. In this respect, such aspects might be useful to know how the writers employ the information to the readers. Besides, it is of benefit to categorize the texts, whether they belong to written or spoken mode. Fourth and the last activity was making the comparison analysis of the register category of the texts. From the comparison, the researcher could determine some kinds of generalizations to the language resources used to express the relationship between language (texts) and context in which they are used.

\section{FINDINGS}

The field was revealed through transitivity patterns and circumstance analysis on the process types. The tenor was seen through mood structure analysis in which the 
writer analyzed the Modality and Adjuncts used in both. In the meantime, the mode was examined by analyzing the conjunction and reference.

\subsection{Field of the Texts}

Table 1. Process type (Transitivity Analysis)

\begin{tabular}{|c|c|c|c|c|c|}
\hline \multirow{2}{*}{$\begin{array}{l}\mathrm{N} \\
\mathrm{o}\end{array}$} & \multirow{2}{*}{$\begin{array}{l}\text { Process } \\
\text { Type }\end{array}$} & \multicolumn{2}{|l|}{ Text I } & \multicolumn{2}{|l|}{ Text II } \\
\hline & & Clause & Total & Clause & Total \\
\hline 1 & Material process & $\begin{array}{l}1 \mathrm{~b}, 1 \mathrm{c}, 1 \mathrm{~d}, 2 \mathrm{a}, 2 \mathrm{~b}, 2 \mathrm{c}, 2 \mathrm{~d}, 2 \mathrm{e}, \\
2 \mathrm{f}, 2 \mathrm{~g}, 6,7,9 \mathrm{a}, 9 \mathrm{~b}, 9 \mathrm{c}, 10,13 \mathrm{~b} \\
, 14 \mathrm{a}, 14 \mathrm{~b}, 15 \mathrm{a}, 17 \mathrm{~b}, 19 \mathrm{a}\end{array}$ & 22 & $\begin{array}{l}1 \mathrm{~b}, 1 \mathrm{c}, 1 \mathrm{~d}, 2 \mathrm{a}, 2 \mathrm{~b}, 2 \mathrm{c}, 2 \mathrm{~d}, \\
6,7,8 \mathrm{~b}, 8 \mathrm{c}, 8 \mathrm{~d}, 8 \mathrm{e}, 9 \mathrm{~b}, 10 \\
\mathrm{~b}, 10 \mathrm{c}, 11,13 \mathrm{a}, 13 \mathrm{~b}, 14 \mathrm{~b}\end{array}$ & 20 \\
\hline 2 & Mental process & $\begin{array}{l}3 \mathrm{c}, 11 \mathrm{a}, 11 \mathrm{~b}, 12 \mathrm{a}, 14 \mathrm{c}, 16 \mathrm{a}, 1 \\
7 \mathrm{a}, 17 \mathrm{c}, 18 \mathrm{a}\end{array}$ & 9 & $3 c, 14 d$ & 2 \\
\hline 3 & Verbal process & $\begin{array}{l}1 a, 3 a, 5 b, 8 b, 12 c, 13 c, 16 b \\
19 b\end{array}$ & 8 & $\begin{array}{l}1 \mathrm{a}, 3 \mathrm{a}, 5 \mathrm{~b}, 9 \mathrm{a}, 13 \mathrm{c}, 14 \mathrm{a}, 1 \\
4 \mathrm{c}\end{array}$ & 7 \\
\hline 4 & Behavioral process & - & 0 & - & 0 \\
\hline 5 & Existential Process & - & 0 & - & 0 \\
\hline 6 & $\begin{array}{l}\text { Relational: } \\
\text { attributive }\end{array}$ & $\begin{array}{l}\text { 4a, } 4 b, 8 a, 13 a, 13 d, 15 b, 18 \\
b, 19 c\end{array}$ & 8 & $\begin{array}{l}2 \mathrm{a}, 4 \mathrm{a}, 4 \mathrm{~b}, 8 \mathrm{a}, 12, \\
14 \mathrm{e}\end{array}$ & 6 \\
\hline 7 & $\begin{array}{l}\text { Relational: } \\
\text { identifying }\end{array}$ & $3 b, 5 a$ & 2 & $3 \mathrm{~b}, 5 \mathrm{a}, 10 \mathrm{a}$ & 3 \\
\hline 8 & $\begin{array}{l}\text { Relational: } \\
\text { possessive }\end{array}$ & $12 b$ & 1 & & 0 \\
\hline
\end{tabular}

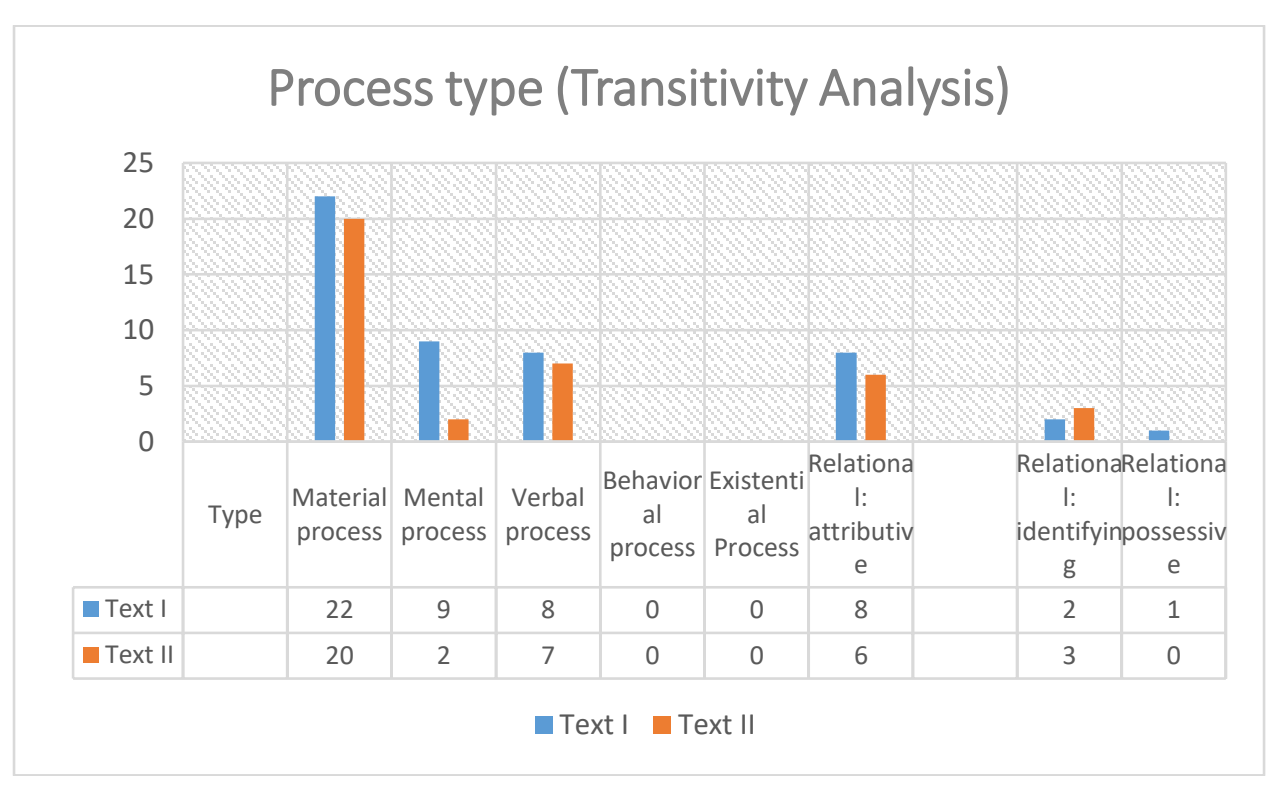


Table 1 and its graph show that the material processes are the most dominant process type used in both texts. This fact points out that both texts are mostly concerned with the actions and events of the participants involved in the texts. Besides, both texts dominantly dealt with substantial and physical actions. In terms of mental process, Text I employed a higher proportion of mental processes than other process types. In this respect, Text 1 was concern more with conscious cognition; the participants' thinking, or feeling on the events. Interestingly, Text I and Text II had an almost equal proportion of verbal processes. It points out that both texts use direct and indirect speech to inform and emphasize what the participants say in the event. Yet, Text I was more scientific descriptive than Text II. It was proven by the use of attributives that were more dominant in the relational category.

Aside from process type, there was another category of lexico-grammar analysis in transitivity structure. The category was about the use circumstances which occur in all process type in transitivity as shown in Table 2 and the graph.

Table 2. Circumstances

\begin{tabular}{|c|c|c|c|c|c|}
\hline \multirow[t]{2}{*}{ No } & \multirow{2}{*}{$\begin{array}{c}\text { Circumstance } \\
\text { Category }\end{array}$} & \multicolumn{2}{|l|}{ Text I } & \multicolumn{2}{|l|}{ Text II } \\
\hline & & Clause & Total & Clause & Total \\
\hline 1 & Extent & $19 \mathrm{a}$ & 1 & - & 0 \\
\hline 2 & Cause & $1 d, 9 b, 14 b$ & 3 & 12 & 1 \\
\hline 3 & Location & $1 d, 2 a, 9 a, 9 c, 10,14 b, 19 a$ & 7 & $1 \mathrm{~d}, 2 \mathrm{a}, 8 \mathrm{c}, 8 \mathrm{~d}, 13 \mathrm{~b}, 14 \mathrm{~b}$ & 6 \\
\hline 4 & Matter & - & 0 & - & 0 \\
\hline 5 & Manner & $13 b, 14 a, 17 b$ & 3 & - & 0 \\
\hline 6 & Role & - & 0 & - & 0 \\
\hline 7 & Accompaniment & $12 \mathrm{~b}$ & 1 & - & 0 \\
\hline
\end{tabular}




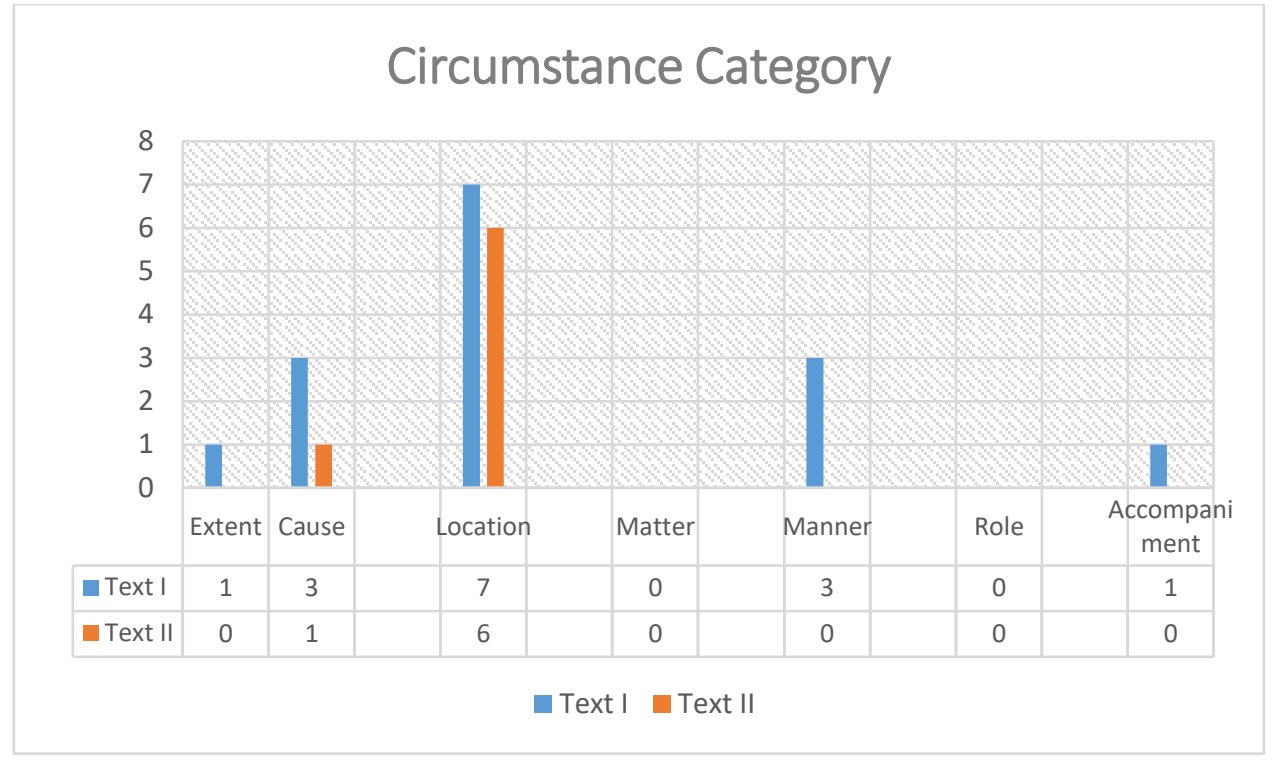

Table 2 and the graph show that Text I employed high number of circumstances than Text II. Looking at the distribution for each type, the location circumstance category was the most proportion in both texts. As such, both texts mostly described when and where the action took place. Yet, the second dominant circumstance in Text I was Cause and Manner indicating information about why and how the actions or events happened. Meanwhile, the proportion of Extent and Accompaniment in Text I was once for each. Unlikely, Text II employed Cause circumstance once and the employment of location circumstance was 6 times. Then, it can be said that Text II only concentrated on where, when, and why the event happened; Text I was concerned with how long, when, where, how, and why the event takes place. In short, Text I was more informative than text II.

\subsection{Tenor of the Texts}

In relation to the lexico-grammar analysis (mood structure) analysis, the writer analyzed the Modality (Table 3 and graph) and Adjuncts (Table 4 and graph) used in both texts.

Table 3. Modality

\begin{tabular}{|c|l|c|c|c|c|}
\hline \multirow{2}{*}{ No } & \multicolumn{2}{|c|}{ Type } & \multicolumn{2}{c|}{ Text I } & \multicolumn{2}{c|}{ Text II } \\
\cline { 3 - 6 } & & Clause & Total & Clause & Total \\
\hline 1 & Modalization & $13 \mathrm{a}$ & 1 & $1 \mathrm{~b}$ & 1 \\
2 & Modulation & $8 \mathrm{~b}$ & 1 & - & 0 \\
3 & Negation & 0 & 0 & - & 0 \\
\hline
\end{tabular}


From Clause to Function: Texts Analysis Using Systemic Functional Linguistics

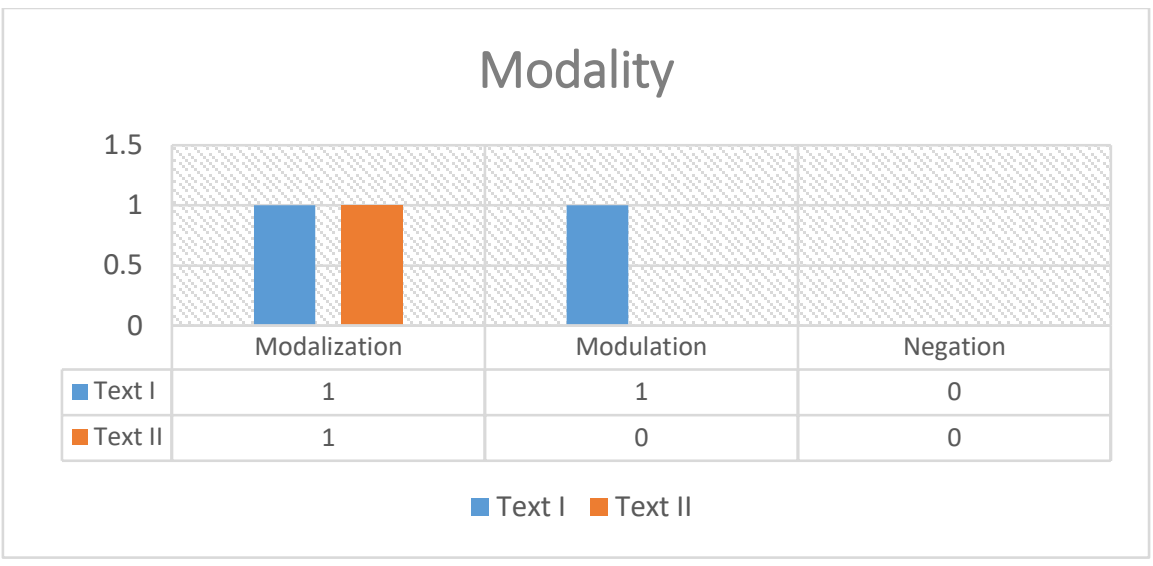

From Table 3 and its graph, both texts rarely used Modality form. The level of modality in both texts was low in which there were not many actions of getting other people to do things. In addition to mood structure analysis, the employment of Adjuncts (Table 4) was necessarily examined.

\section{Table 4. Adjuncts}

\begin{tabular}{|c|c|c|c|c|c|}
\hline \multirow{2}{*}{ No } & \multirow{2}{*}{$\begin{array}{l}\text { Type of } \\
\text { adjuncts }\end{array}$} & \multicolumn{2}{|l|}{ Text I } & \multicolumn{2}{|l|}{ Text II } \\
\hline & & Clause & Total & Clause & Total \\
\hline 1 & Circumstantial & $\begin{array}{l}\text { 1d,2a,9a,9b,9c,10,12b,13b, } \\
14 \mathrm{~b}, 17 \mathrm{~b}, 18 \mathrm{a}, 19 \mathrm{a}\end{array}$ & 12 & $1 \mathrm{~d}, 2 \mathrm{a}, 8 \mathrm{c}, 8 \mathrm{~d}, 14 \mathrm{~b}$ & 5 \\
\hline 2 & Mood & $2 \mathrm{c}$ & 1 & $13 \mathrm{a}, 14 \mathrm{a}$ & 2 \\
\hline 3 & Polarity & - & 0 & - & 0 \\
\hline 4 & Comment & $1 b$ & 1 & $1 b$ & 1 \\
\hline 5 & Vocative & - & & - & 0 \\
\hline 6 & Conjunctive & $\begin{array}{l}\text { 1d,2a,2f,2g,3a,3c,5a,9a,9c, } \\
10,11 \mathrm{a}, 13 \mathrm{c}, 14 \mathrm{c}, 15 \mathrm{a}, 18 \mathrm{~b}, 19 \mathrm{~b}\end{array}$ & 16 & $\begin{array}{l}2 \mathrm{a}, 2 \mathrm{c}, 3 \mathrm{a}, 5 \mathrm{a}, 8 \mathrm{~d}, 13 \mathrm{~b}, 14 \mathrm{~d}, \\
14 \mathrm{e}\end{array}$ & 8 \\
\hline 7 & Continuity & - & 0 & - & 0 \\
\hline
\end{tabular}




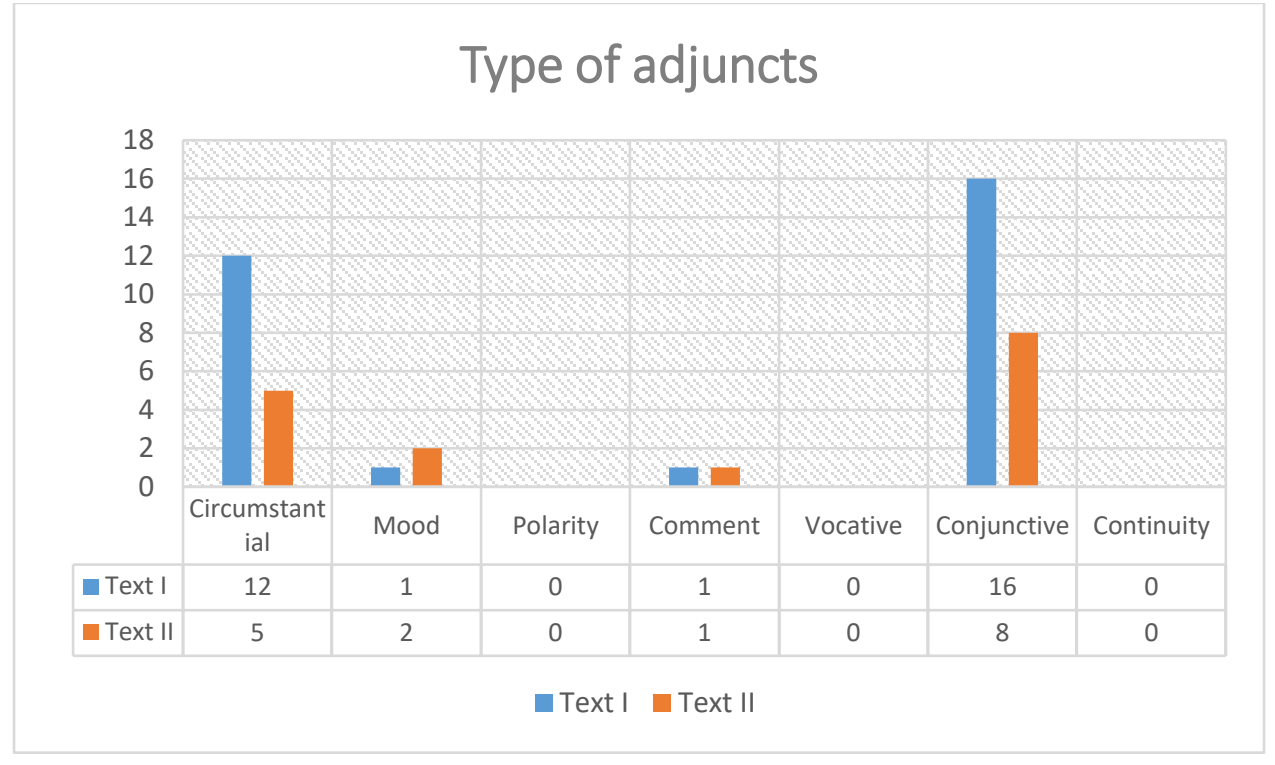

Table 4 and its graph show that Text I had a higher number of adjuncts than Text II. The Conjunctive adjunct was the most dominant type appeared in Text I. The highest proportion of this adjunct indicates more rhetorical organization of this text. The second most dominant in Text I was circumstantial adjunct type. It shows that the text was more detailed in describing the events. Mood and Comment adjuncts were less used in Text I delineating less probability in the text. Although different in number, Text II was similar to Text I in terms of the appearance of conjunctive adjunct. The second dominant adjunct type in this text was Circumstances adjunct.

From this fact, it can be seen that both texts put conjunctive adjuncts as the highest proportion and circumstantial adjunct as the second dominant proportion of adjuncts used. Highlighting the number of proportions, there is a strict difference of both texts that is the text I has most amount in both adjuncts indicating Text I was more rhetoric of text organization and more detail in describing the event than text II.

\subsection{Mode of the Texts}

The mode is concerned with the way the writers express his/her idea in the text. The use of conjunction (Table 5) and reference (Table 6) is of benefit to investigate which subsequently determines the mode itself.

Table 5. Conjunction

\begin{tabular}{|c|l|c|c|c|c|}
\hline \multirow{2}{*}{ No } & \multirow{2}{*}{$\begin{array}{c}\text { Types of } \\
\text { Conjunction }\end{array}$} & \multicolumn{2}{|c|}{ Text I } & \multicolumn{2}{c|}{ Text II } \\
\cline { 3 - 6 } & & Explicit & Implicit & Explicit & Implicit \\
\hline 1 & Elaborating & - & 1 & - & 1 \\
2 & Extending & 8 & 1 & 5 & 1 \\
3 & Enhancing & 3 & 4 & 1 & 1 \\
\hline
\end{tabular}




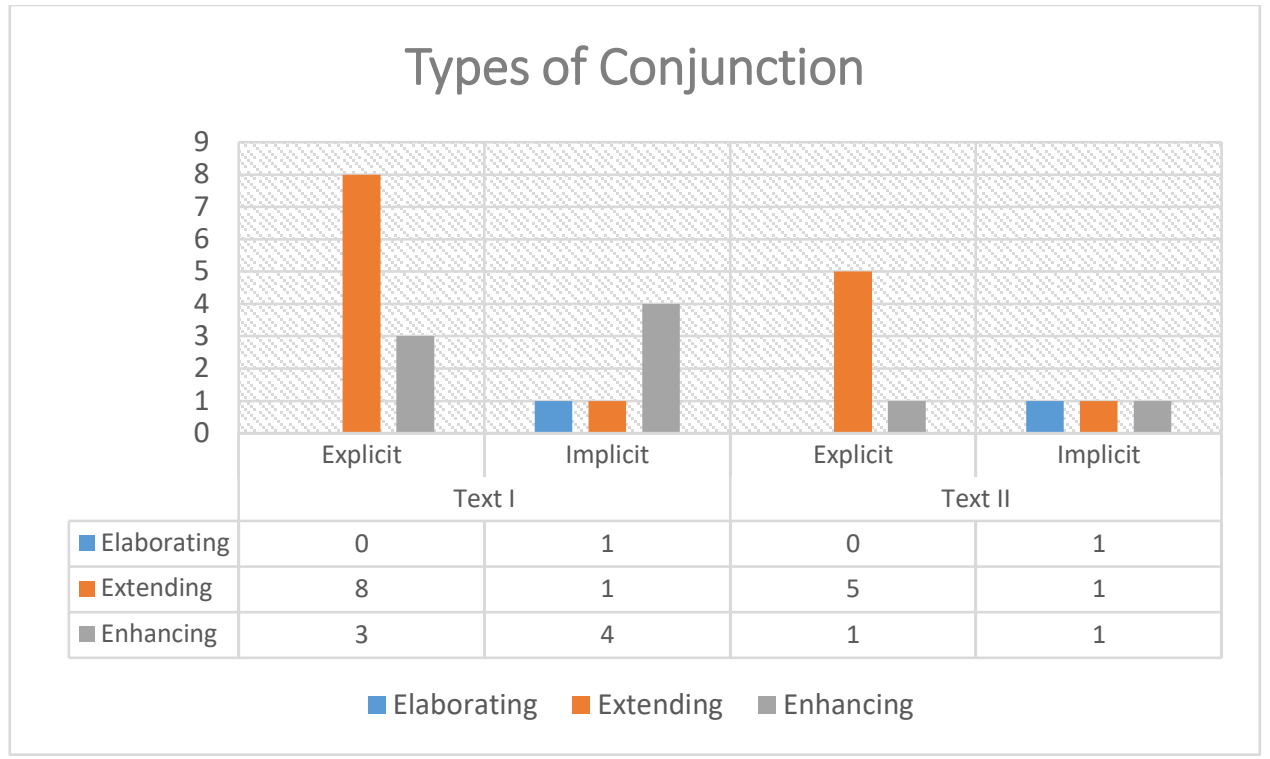

Table 5 and its graph show that Text I has a more explicit conjunctive structure which is very common in written text. The dominant category was extension conjunction. This fact shows that Text I was concerned more about giving additional information and various changes of information by contradicting it. Besides, the text was more related to extending the information in terms of time and the cause of the information given. The text was less concerned with explaining information by restating it in another way. Similarly, Text II has also a more explicit conjunctive structure. The domain category was an extension category suggesting the concern of giving additional information and variation of changes of information by contradicting it. Looking from the conjunctive category, Text I had more number of conjunctions implying more explanative in giving additional or variations of information and in extending the cause of information.

Another way to decide the mode of the text is by doing reference analysis. The link of reference items and their referents were summarized in Table 6.

Table 6. Reference

\begin{tabular}{|c|l|c|c|}
\hline \multirow{2}{*}{ No } & Types of Referential Cohesion & Text I & Text II \\
\cline { 3 - 4 } & & Total & Total \\
\hline 1 & Homophoric & 5 & 3 \\
2 & Exophoric & 1 & 3 \\
3 & Endophoric & 42 & 24 \\
& a. Anaphoric & 2 & - \\
& b. Cataphoric & - & - \\
& c. Esphoric & & \\
\hline
\end{tabular}

Indonesian Journal of EFL and Linguistics, 6(1), 2021 


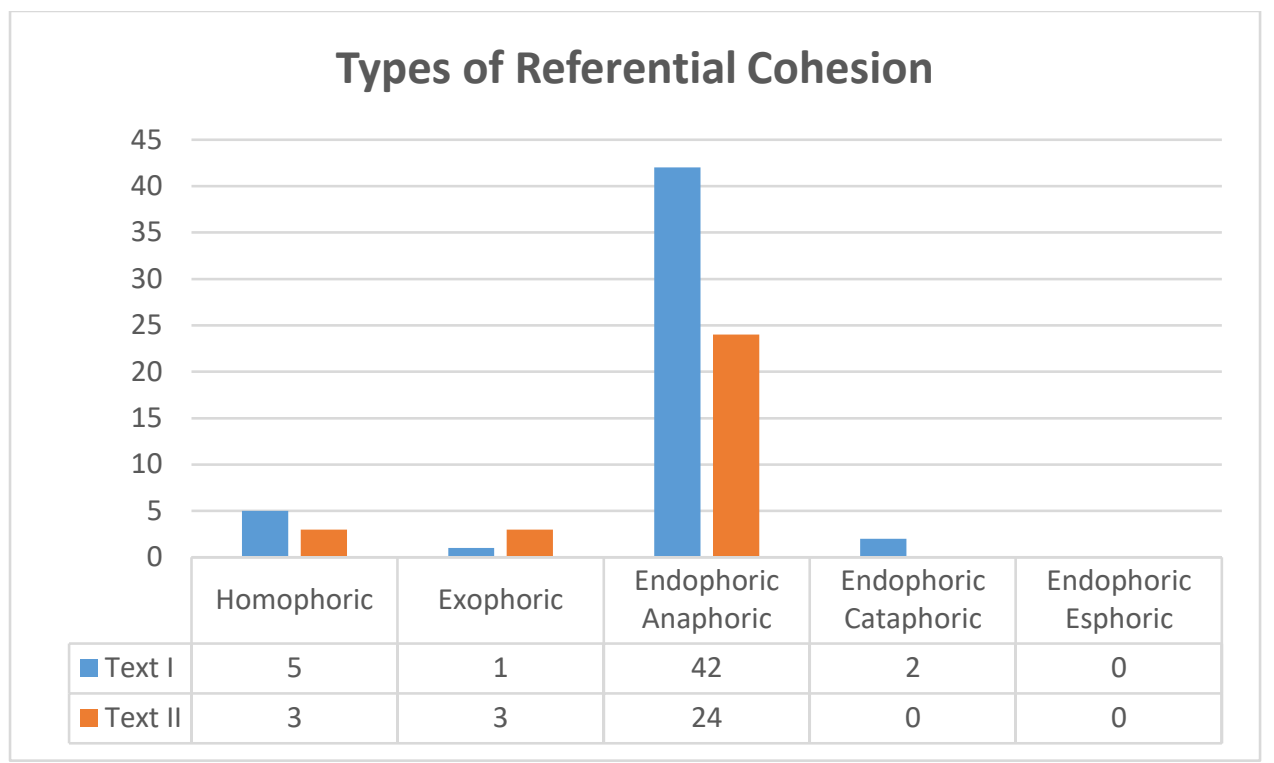

\section{DISCUSSION}

Looking at the data, there is a huge difference in the number of reference chains in the texts. Yet, both texts mostly used anaphoric type of referential cohesion. The text I has few major participants i.e. Thierry Henry, Irish, the referee, you, and team, while Text I (table 11) has only three major participants i.e. Thierry Henry, the referee, and Robbie Keane. Those participants were personal, particular, and developed consistently in each text. Thus, from the table, it can be concluded that the reference was mostly text-internal form not contextual and situational characterizing the written mode.

By and large, several important points can be proposed from this study. First, through transitivity process types analysis, both texts were mostly concerned with physical actions and events of the participants involved in the texts and employed both direct and indirect speech to inform what they said in the event. Yet, utilizing mental and relational process types, Text 1 highlighted more on conscious cognition, the participants' thinking or feeling, more scientific descriptive, and more informative than Text II. This reflects the previous finding of Tolochko \& Boomgaarden (2017) and Bartley (2018), revealing that patterns of presenting information across various genre are different and the verbs in a clause constitute a process type with each verb contributing to the intended meaning of the structure

Second, the interpersonal function plays the role of setting up and maintaining social relations and indicates the roles of the participants in the texts. We use language to interact with people for some purposes that are to influence their attitudes or behavior or to provide information that they do not know or to explain our attitudes or behavior, or to get them to take some actions, (Darong, Effendi, Basthomi, 
Hidayati, Niman, 2020). In this respect, the level of modality in both texts was low in which there were not many actions of getting other people to do things. Besides, employing adjunct, Text I was more rhetoric of text organization and more detail in describing the event than text II. As such, the lexico-grammar used might carry the system of interpersonal meaning differently resulting from a paradigmatic description of context (Andersen et al., 2018; Hasan, 2014; Darong, 2015). Moreover, In agreement with (Murthy \& Kumar, 2007; Xuan, 2017; Montes, Barboza, \& Olascoaga, 2014)), a particular text may employ a particular distinctive characteristic among language used

Third, the concept of mode is concerned with the nature of a text whether a text is categorized as spoken or written the mode. As both texts mostly used an anaphoric type of referential cohesion (Eggins, 1994), they belong to written mode. Besides, the logical relations appearing in the texts were concerned with the link of the preceding and following clause. The link is regarded as in terms of a relationship of addition; one sentence adds to the meanings made in another (extension), of a relationship of restatement or clarification (Elaboration) or even of an enhancement. In this respect, Text I had more number of conjunctions implying more explanative in giving additional or variations of information and in extending the cause of and effect relation of the information. This mirrors previous studies saying that the coherence of information showing cause and effect relation is fully achieved in short text encoding logico-semantic meaning (Kai, 2008; Murthy \& Kumar, 2007; Othman, 2020; Poulimenou et al., 2016). As such, Halliday's systems of meaning are effective tools to unlock the meaning-potential in clauses underlying ideologies in news reports (Potter, 2016).

Of greater importance of this finding is that there should be a paradigmatic description of context implying meaning, system, and metafunction of language as a particular text may employ a particular distinctive characteristic among language used. In this regard, the text analysis should be carried out in such a way that it might not only cope with the ideology and macro aspects but also the discoursesemantics aspects employing experiential, interpersonal, and textual meanings and the lexico-grammar functions which is realized by register category of field, tenor, and mode. By now, how could the analysis of these texts employs pedagogical implication? This important question might lead us to an understanding of Systemic Functional Linguistics (SFL) that has had a great impact on language teaching.

In the context of pedagogy, the experiential function examination which is grasped by register category of field of a text divulges how writers constitute their experience differently by choosing different language components. Teachers might obviously and systematically provide the range of choices available for expressing human experience in an English clause construction through the knowledge of experiential potential meaning of the grammar. In this regard, the different process types such as material, mental, relational verbal, relational and attributive different 


\section{Hieronimus Canggung Darong}

participant roles used in such process types such as goal, actor, carrier, sayer, sensor, token and so forth, and the types of circumstances might be included. Of greater importance of this highlight in question, as the experiential grammar employed to make a text is stimulated by the objective to be achieved by the text. The teachers might provide activities making learners to prospect the relations between experiential grammar, text structure and field through field of the immediate situation within the clause.

In relation to interpersonal examination of the texts, what is crucial to be successful in language teaching is classroom interaction. One should persistently put together options of many different kinds such as what and how we want to say or write and the particular sentences formulations, words, and sounds that best unify the what and the how in question. As coined by Wardaugh (1986), how we say something is at least as important as what we say. As such students' misfiring in classroom interaction that evolves in negotiation of meaning, needs a delineation or restructuring of message come up with language interpersonally. The interpersonal function analysis of the texts under study would be of benefit for both teacher and students to interact each other, to exchange proposition, and to express a viewpoint or position. The system of Subject and Finite as made in the texts under study reflects how such position or proposition is reciprocated. Foregoing statement is constructed to provide information that is usually composed by the subject position preceding the finite in the clause. While, demanding information as teacher wants to raise questions, the subject position may follow or precede the finite in the clause.

Besides, one challenging case of teaching is about how to build and maintain social relationships in classroom interactions. The students may go with how tenor is employed in interactions by looking at what grammar constitutes about the relative power and status of the teacher, and their level of personal involvement. Then, it makes sense that the pedagogical implication of the analysis of the texts under study is found through the use of modality (modalization, modulation, negation) and adjuncts. As such, the teachers can design some pragmatics teaching activities for the sake of constructing an interpersonal relation, maintains the relationship, influences behaviour, viewpoint, (Eggins, 1994).

The third metafunction namely mode of the texts under study is the realization of textual meanings working with both experiential meaning and interpersonal meaning together in coherent and lucid language. This means that analysing textual grammar might be of benefit to enhance language teaching from many points. In this respect, texts under study which realizes the significance of theme in a clause is regarded as an important feature of the texts. Theme is what is the message is concerned with (Halliday, 1985). Appearing as the first position, it indicates what the message is about. Yet, it is not only a point of departure of a clause, but also a notice to where the meanings have derived from and where they are departing. In this context, the teacher has to teach his or her students both what the clause is concerned with and 
link them into the context. Consequently, the students must make their texts, both spoken and written mode, logical and coherent through suitable textual themes and topical Themes. As such, teacher should teach them in such a way that he or she includes such essential grammatical features as the topic sentence, sequencing conjunctions, and reference which, if not essential, are at least particularly of benefit for proficient communication.

Thus, it is unalike with all the foregoing models of grammar in that it views language as interconnected sets of choices for meaning construction and look up to furnish a clear relation between functions and grammatical order. Besides, from a functional perspective, language is seen more than vocabulary and rules of grammar; instead, it is a business of meaning construction, working the meaning together coherently, and making them into purposeful texts to its context. As such, it has such a great impact and of benefit for a teacher in language teaching-learning process.

\section{CONCLUSION}

Based on the discussion of both texts, the writer may take some conclusions. First, empirically, this texts analysis confirms that the unity of text appears the linguistic resources used properly in context. Going deeper into the context of the instructional approach, SFL has had a great impact in language teaching. SFL employed in the texts under study might scaffold students to reveal the meanings lies behind the texts as the realization of the three metafunctions namely experiential, interpersonal and textual which are respectively realized by register category of field, tenor, and mode. Second, methodologically, the SFL is not only of benefit to reveal thematic information within the text but also is useful to examine the meaning construction through the lexico-grammar used within the clause of the texts. Of greater importance of this approach is that its pedagogical implication for both teacher and students, both written and spoken mode, in language classroom interaction

Yet, this study suffered from some limitations. First, the study was only concerned with the metafunctions of language which are realized by register category of field, tenor, and mode. As such, under the approach of SFL, they belong to the context of situation. Meanwhile, SFL also puts another context to deal with that is the context of culture or genre of the text. Therefore, further studies might be more challenging by covering both contexts (situation and culture) at once. Second, this study is purely a linguistics analysis in written texts. Further studies need to examine deeper how this approach is employed in spoken texts.

\section{REFERENCES}

Andersen, T. H., Emilie, A., \& Holsting, M. (2018). Clause complexing in systemic functional linguistics - towards an alternative description. Functional Linguistics, 5(10), 1-25. https://doi.org/https://doi.org/10.1186/s40554-0180059-7 
Hieronimus Canggung Darong

Bao, C., Zhang, X., Qu, Y., \& Feng, Z. (2018). American English Perfect Construction Across Registers. Journal of Quantitative Linguistics, 25(4), 314341. https://doi.org/10.1080/09296174.2017.1387961

Bartley, L. V. (2018). Putting transitivity to the test: a review of the Sydney and Cardiff models. Functional Linguistics, 5(4), 1-21.

Bartholomé, G., Lecheler, S., \& Vreese, C. De. (2018). Towards A Typology of Conflict Frames: Substantiveness and interventionism in political conflict news. Journalism Studies, 19(12), 1689-1711. https://doi.org/10.1080/1461670X.2017.1299033

Boch, A. (2020). Increasing American Political Tolerance: A Framework Excluding Hate Speech. Socius: Sociological Research for a Dynamic World Volume, 6, 1-12. https://doi.org/10.1177/2378023120903959

Boczkowski, P. J., Mitchelstein, E., \& Suenzo, F. (2020). The Smells, Sights, and Pleasures of Ink on Paper: The Consumption of Print Newspapers During a Period Marked by Their Crisis. Journalism Studies, 21(5), 565-581. https://doi.org/10.1080/1461670X.2019.1670092

Brookes, G., \& Mcenery, T. (2019). The utility of topic modeling for discourse studies: A critical evaluation. Discourse Studies, 21(1), 3-21. https://doi.org/10.1177/1461445618814032

Darong, H. C. (2015). Manggarain Candidate Ruler's Jargon 2015 and Its Pedagogical Implications in Language Teaching. Missio, 7(2), 278-296.

Darong, H. C., Kadarisman, A. E., Basthomi, Y., Suryati, N., Hidayati, M., \& Niman, E. (2020). What Aspects of Questions Do Teachers Give Attention To? International Journal of Innovation, Creativity, and Change, 10(11), 191-208.

Eggins, S. (1994). An Introduction to Systemic Functional Linguistics. London: Pinter

Fetzer, A., \& Bull, P. (2012). Doing leadership in political speech: Semantic processes and pragmatic inferences. Discourse \& Society, 23(2), 127-144. https://doi.org/10.1177/0957926511431510

Franklin, B. (2014). The Future of Journalism In an age of digital media and economic uncertainty. Journalism Studies, 15(5), 481-499. https://doi.org/10.1080/1461670X.2014.930254

Harcup, T., \& Neill, D. O. (2017). What is news? News values revisited (again). Journalism Studies, 18(12), 1470-1488. https://doi.org/10.1080/1461670X.2016.1150193

Halliday, M. A. K. (1985). An introduction to functional grammar. London: Arnold.

Hasan, R. (2014). Towards a paradigmatic description of context: systems, metafunctions , and semantics. Functional Linguistics, 1(9), 1-54. https://doi.org/http://www.functionallinguistics.com/content/

Guswita, K. A., \& Suhardi. (2020). Transitivity Analysis of Jokowi and Prabowo Campaign Speech in Indonesian Presidential Election 2019. Indonesian Journal of EFL and Linguistics, 5(1), 143-158. 
Kai, J. (2008). Lexical Cohesion Patterns in NS and NNS Dissertation Abstracts in Applied Linguistics: A Comparative Study. The Linguistics Journal, 3(3), 132144.

Kelly, C. R. (2020). Donald J . Trump and the rhetoric of ressentiment. Quarterly Journal of Speech, 106(1), 2-24. https://doi.org/10.1080/00335630.2019.1698756

Koivukoski, J., \& Ödmark, S. (2020). Producing Journalistic News Satire: How Nordic Satirists Negotiate a Hybrid Genre. Journalism Studies, 21(6), 731-747. https://doi.org/10.1080/1461670X.2020.1720522

Leong, P. A. (2019). Visualizing Texts : a tool for Generating Thematic-progression Diagrams. Functional Linguistics, 6(4), 1-13. https://doi.org/https://doi.org/10.1186/s40554-019-0069-0

Lim, F. V. (2018). Developing a systemic functional approach to teach multimodal literacy. Functional Linguistics, 5(13), 1-17. https://doi.org/https://doi.org/10.1186/s40554-018-0066-8

Lule, J. (2007). War and its metaphors: news language and the prelude to war in Iraq, 2003. Journalism Studies, 5(2), 179-190. https://doi.org/10.1080/1461670042000211168

Martin, J. R., \& Zappavigna, M. (2019). Embodied meaning: a systemic functional perspective on paralanguage. Functional Linguistics, 6(1), 1-33. https://doi.org/https://doi.org/10.1186/s40554-018-0065-9

Mishra, S. (2020). From \# MeToo to\# MeTooIndia: News Domestication in Indian English Language Newspapers. Journalism Studies, 21(5), 659-677. https://doi.org/10.1080/1461670X.2019.1709882

Montes, P. A. , Barboza, A. M.., \& Olascoaga, A. I. (2014). Systemic Functional Linguistics and Discourse Analysis as Alternatives When Dealing With Texts. Profile, $\quad$ 16(2), 101-116. https://doi.org/http://dx.doi.org/10.15446/profile.v16n2.38113.

Moragas-fernández, C. M., Calvo, M. M., \& Capdevila, A. (2018). The process en route: the metaphor of the journey as the dominant narrative for the political discourse in Catalonia. Critical Discourse Studies, 15(5), 1-23. https://doi.org/10.1080/17405904.2018.1468787

Murthy, K. N., \& Kumar, G. B. (2007). Language identification from small text samples *. Journal of Quantitative Linguistics, 13(1), 57-80. https://doi.org/10.1080/09296170500500694

Naab, T. K., Heinbach, D., \& Ziegele, M. (2020). Comments and Credibility : How Critical User Comments Decrease Perceived News Article Credibility. Journalism Studies, 21(6), 783-801. https://doi.org/10.1080/1461670X.2020.1724181

Nartey, M. (2018). ' I shall prosecute a ruthless war on these monsters ... ': a critical metaphor analysis of discourse of resistance in the rhetoric of Kwame Nkrumah. Critical Discourse Studies, 16(2), 1-18. 
https://doi.org/10.1080/17405904.2018.1535987

Othman, W. (2020). Causal relations on a Cline of Explicitness: an SFL Perspective. Functional Linguistics, 7(2), 1-14. https://doi.org/doi.org/10.1186/s40554-020-00071-2

Peter, C., \& Zerback, T. (2020). Ordinary Citizens in the News: A Conceptual Framework. Journalism Studies, 21(8), 1003-1016. https://doi.org/10.1080/1461670X.2020.1758190

Potter, L. (2016). Ideological representations and Theme-Rheme analysis in English and Arabic news reports: a systemic functional approach. Functional Linguistics, 3(5), 1-20. https://doi.org/10.1186/s40554-016-0028-y

Poulimenou, S., Stamou, S., Papavlasopoulos, S., \& Poulos, M. (2016). Short Text Coherence Hypothesis Short Text. Journal of Quantitative Linguistics, 23(2), 191-210. https://doi.org/10.1080/09296174.2016.1142328

Rice, C., \& Taylor, M. (2020). “ Reconciliation Isn' t Sexy ": Perceptions of News Media in Post-Conflict Northern Ireland “. Journalism Studies, 21(6), 820-837. https://doi.org/10.1080/1461670X.2020.1724183

Schumacher, G., Hansen, D., Velden, M. A. C. G. Van Der, \& Kunst, S. (2019). A new dataset of Dutch and Danish party congress speeches. Research and Politics, 6(2), 1-7. https://doi.org/10.1177/2053168019838352

Tolochko, P., \& Boomgaarden, H. G. (2017). Analysis of Linguistic Complexity in Professional and Citizen Media. Journalism Studies, 19(12), 1786-1803. https://doi.org/10.1080/1461670X.2017.1305285

Vermeer, S., \& Trilling, D. (2020). Toward a Better Understanding of News User Journeys: A Markov Chain Approach. Journalism Studies, 21(7), 879-894. https://doi.org/10.1080/1461670X.2020.1722958

Wardaugh, R. 1986. An Introduction to Sociolinguistics. New York: Basil Blackwell Ltd.

Wenzel, A. D., Ford, S., \& Nechushtai, E. (2019). Report for America, Report about Communities: Local News Capacity and Community Trust. Journalism Studies, 21(3), 287-305. https://doi.org/10.1080/1461670X.2019.1641428

Works, W., \& Wong, J. S. (2019). Using Crime News Reporting Themes to Predict Image Inclusion in Newspaper Homicide Articles. Journalism Studies, 21(4), 425-442. https://doi.org/10.1080/1461670X.2019.1670719

Xuan, W. W. (2017). An exploratory study of ESL writing by junior secondary students in China: text type, register, and textual features. Functional Linguistics, 4(3), 1-19. https://doi.org/10.1186/s40554-016-0038-9 